\title{
Factors Related to Elder Abuse within the Family
}

\author{
Rahimi $\mathrm{V}^{1}$, Heidari $\mathrm{M}^{*}$, Nezarat $\mathrm{Sh}^{3}$, Zahedi $\mathrm{A}^{4}$, Mojadam $\mathrm{M}^{5}$, Deris $\mathrm{S}^{6}$
}

\begin{abstract}
Introduction and purpose: Elder abuse is a type of family violence that has recently been recognized as an extensive and growing social dilemma. Therefore, this study aims to identify elder abuse and its related factors within the families.

Materials and methods: This descriptive-cross sectional study used convenience sampling method to collect 251 elderly admitted to surgery and internal wards in Abadan city. Data were collected using "misbehavior to elderly in family" questionnaire via face to face interviews. Data analysis was done by SPSS software version 16 using descriptive statistics, Chi-square and Spearman correlation coefficients.

Findings: Findings from the current study showed that the highest type of abuse was care negligence (62.8\%) followed by authority deprival (48.6\%) psychological misbehavior (41\%), financial abuse (36.7\%), financial negligence (36.5\%), emotional negligence (36\%), physical misbehavior (27.4\%) and lastly ostracism $(25.6 \%)$. There was a significant relationship between care negligence and age. Psychological misbehavior was significantly associated with number of children. In addition, physical negligence was significantly associated with age and income. However, there was a significant relationship between financial misbehavior and marriage status.

Conclusions: Financial negligence and authority deprival are the most frequent type of misbehavior among elderly. Factors related to misbehavior in the elderly are age, marital status, number of children and income. Cooperation and participation of all related organizations are necessary to mitigate misbehavior with elderly within the family.
\end{abstract}

Key words: Elder, Abuse, Family

Received: 2016/11/4 Accepted: 2016/12/5

Copyright (C) 2018 Quarterly Journal of Geriatric Nursing.This is an open-access article distributed under the terms of the Creative Commons Attribution international 4.0 International License(http://creativecommons.org/licenses/by /4.0/) which permits copy and redistribute the material, in any medium or format, provided the original work is properly cited.

1 - BSc, Nursing Student, Student Research Committee, Abadan School of Medical Sciences, Abadan, Iran.

2 - MSc, Lecturer at Medical Surgical Nursing department, Abadan School of Medical Sciences, Abadan, Iran.

(Corresponding Author):E-mail: heidari.maryam84@yahoo.com

3 - BSc, Nursing Student, Student Research Committee, Abadan School of Medical Sciences, Abadan, Iran.

4 - MSc, Lecturer at Epidemiology department, Abadan School of Medical Sciences, Abadan, Iran.

5 - BSc, Nursing Student, Student Research Committee, Abadan School of Medical Sciences, Abadan, Iran.

6 - BSc, Nursing Student, Student Research Committee, Abadan School of Medical Sciences, Abadan, Iran. 


\section{سوءرفتار با سالمند در خانواده و عوامل مرتبط با آن}

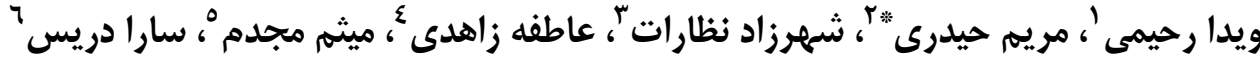

تاريخ دريافت مقاله:

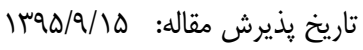

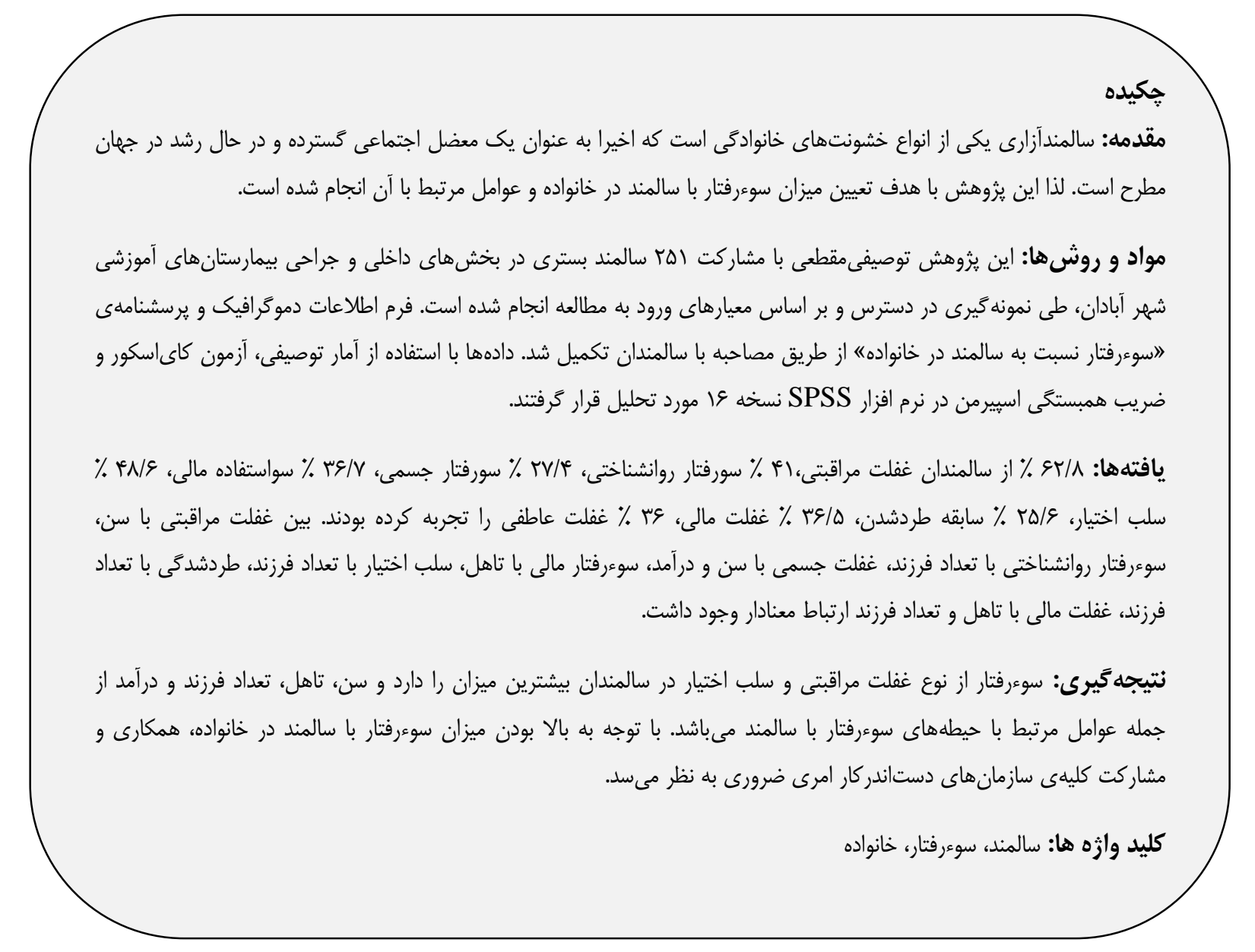

ا- دانشجوى كارشناسى يرستارى، كميته تحقيقات دانشجويى، دانشكده علوم يزشكى آبادان، آبادان، ايران.

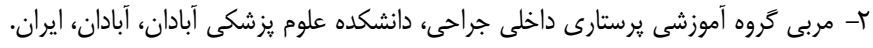

(نويسنده مسؤول). يست الكترونيكى: Heidari.maryam84@yahoo.com

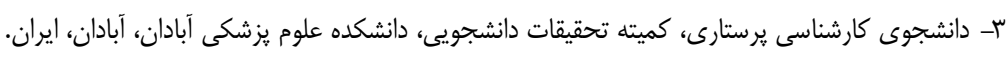

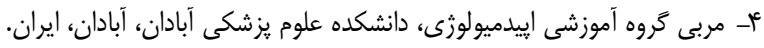

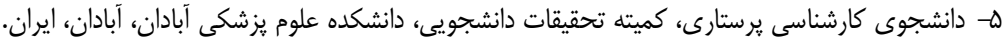

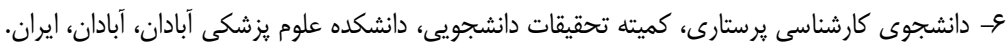


تظاهر يابد(Y). سوءرفتار با سالمند بر حسب مكان وقوع و مرتكـب آن به دو دستهى كلى: خـانكى و سـازمانى تقسيم مسىشـود كـهـ سوءرفتار خانكىى، در منزل يا محل زندگى سالمند توسـط اعضـاى

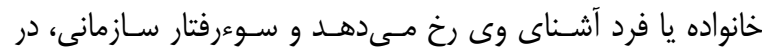
خانهى سالمندان يا مراكز مراقبت طولانىمدت توسط كاركنان اين مراكز يا مراقبين غريبه رخ مىدهد((). نتايج حاصـل از مطالعـهاى وسيع در ايالات متحدة آمريكا حاكى از آن بـود كـه بـيش از ـ 1. درصد از جوامع سالخورده با مسـألهى سـوءرفتار، در حـال زنـدَىى هستند و يا به طور بالقوه طى سال هاى گذشته ناديده گرفته شدهاند(أ). برخى مطالعات نيز مدعى هستند كـه سـوءرفتار نسـبت بــــ سالمندان به طور عمده در منازل رخ مىدهد و اين ميزان بـين تا س/س/ درصد از كل موارد سوء رفتار نسبت به سالمندان حَزارش شده است(ب). بــهــلاوه، شـواهد حـاكى از آن اسـت كـه شـيوع سوءاستفادهى مالى نسبت به سوءاستفادهى روانى، تقريبا" س برابـر بيشتر است(أ). بيشتر سوءرفتار كنندكان با سالمندان افـراد خـانواده هستند(ه). يافتههاى حاصل از بررسىها در مركز ملى سوءرفتار بـاــا سالمندان در آمريكا نشان داده اسـت كـه: ایـ٪ سـوءرفتار كنندكان

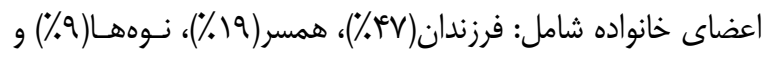
برادر يا خواهر سالمند(و٪) مىباشند و دو سوم قربانيان سـوءرفتار، زنان سالمند هستند(؟). به علاوه، برخى مطالعات نشان دادهاند كه سوءرفتار كلامى، رايجترين نوع سوءرفتار با سالمندان بوده و بعد از آن به ترتيب سوءرفتار مالى، سوءرفتار فيزيكى، غفلت، آزار و اذيت رايج مىباشد(ه). در حقيقت سوءرفتار يك عامل تهلديدكنندهى بقـا

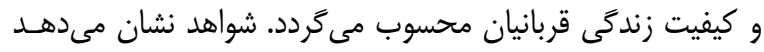
سوءرفتار نسبت به سالمندان يكـى از علـل قابـل توجـه صــدات
طى نيمهى دوم قرن بيسته، جهان با افزايش جمعيت سـالمندان و پِيدهاى به نام خاكسترى شدن جمعيت يا سالمندى اجبارى رو بــه رو بوده است( (). جمعيت جهانى سالمندان (افراد •\& سال و بـالاتر)

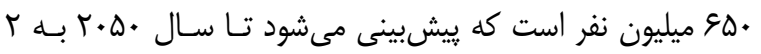

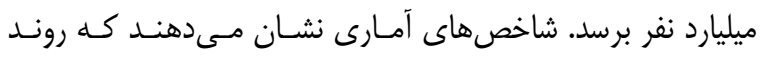
سالمند شدن جمعيت ايران نيز در حال گسترش است، به گونسهاى كه در سرشمارى سال هVIrا، ع/ع درصد از جمعيت كشور را افـراد • ع سال و بالاتر تشكيل دادند و ايـن نسـبت در سرشـمارى سـال.

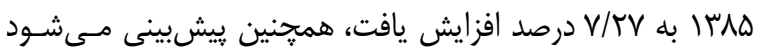

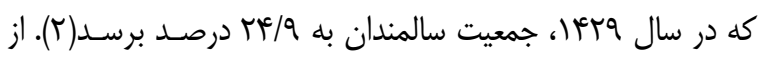
جمله يِامدهاى افزايش جمعيت سالمندان در خانوادهها مىتوان به اثـرات منفـى وضـعيت جسـمى و ذهنسى، فشـارهاى اقتصـادى، اختلالات روانى و تنش هاى عاطفى، عـدم تحمـل بـار مســوليت، خستخى فردى و انزواى اجتماعى افراد خانواده و درنتيجه، افزايش بروز رفتارهاى ضداجتماعى و خشـونت اشـاره نمـود. سـوءرفتار بـاــا سالمندان يا سالمندآزارى يكى از انواع خشونتهاى خانوادگى بوده كه در جوامع امروزى از معضلات عمدهى سلامت به شـمار مسىرود(1). به طورى كه، طى سالهاى اخير به عنـوان يـك مشـكل مهرم در بهداشت عمومى و به عنوان يك مشكل اجتماعى گسترده و در حال رشد در سراسر جهـان مطـرح كرديـده اسـت. يديـدهى سالمندآزارى براى اولين بـار در سـال 19vه تحـت عنـوان وازَهى Granny Battering توصيف شد(ّ) و ممكن است به اشكال مختلف نظير؛ سهلانحَارى و غفلـت در تـأمين نيازهـاى جسـمى سالمند، سوءرفتار روانشناختى، بهرهبردارى مـالى، ناديـده گـرفتن حقوق سالمند و حتى موارد هتـ حرمت توسـط اعضـاى خـانواده 
عواطف حاكم بر والدين و فرزندان تاكيد دارد(T) و با در نظر داشتن

نقش يرستاران در جامعه به دليل ارتباط آنان با تمام اقشار جامعه و نقش حياتى آنان در شكستن هرخه خشونت در زندگى سالمندان و در نتيجــه يِيشـحيرى از عـوارض وسـيع آن در سـطح جامعـه، يُوهشكَران بر آن شدند تـا در ايـن يـروهش بــهـ بررسـى عوامـل مرتبط با سوءرفتار با سالمندان در خانواده در شهر آبادان ببردازند تا بدين طريق با شناسايى اين عوامل، كامى موثر در راستاى ارائسى راهكارهاى اثربخش جهت مقابله با كَسترش اين معضـل برداشـته

\section{مواد و روشها}

يزوهش حاضر از نوع توصيفى مقطعى اسـت، كـه هـس از كسـب مجوز و هماهنكَى لازم با مســولين، بـا مشـاركت زنـان و مـردان سالمند بسترى در بيمارستانهاى آموزشى منتخب دانشـكده علـوم يزشكى آبادان در سال هوسا انجام شــه اسـت. حجـم نمونـه بـر اساس مطالعات مشابه با استفاده از فرمول زير و با در نظر گَرفتن

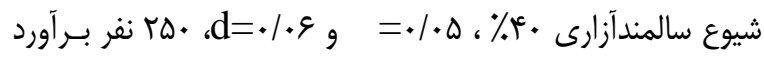
شد(أ). نمونهَيرى به روش در دسترس و با مراجعه به بخشهاى داخلى و جراحى بيمارستانهاى آموزشى آيت ا... طالقانى و شـهيد

$$
\begin{aligned}
& \text { بهشتى آبادان صورت كرفت. } \\
& n=\frac{\left(Z_{1-\frac{\alpha}{2}}\right)^{2} \cdot p \cdot q}{d^{2}}
\end{aligned}
$$

فيزيكـى بيمـارىهـا، از دسـت رفـتن كـارايى، انـزوا، درمانـدَىى، بيخانكَى، كَناه، ترس، خجالـ، انكـار سـوءرفتار، يـأس، ناميـدى،

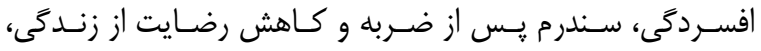

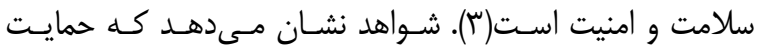
اجتماعى به فاكتورهاى اجتماعى- اقتصادى و جغرافيايى در كروههاى سنى مختلف، بستخى دارد(؟). كاه نرسيدن به مرحلهى بلـوغ فرزندى يا قبول مسوليت به صورت اجبارى، همجنين تحول نقش خانواده، بحرانهاى موجود، فشارهاى روانى زندگى مدرن و ضعف ايمـان קايخــاه اجتمـاعى سـالمند را سستـت نمـوده و سـبب بـروز سوءرفتار توسط اعضاى خانواده نسبت به سالمند مى گـردد. هرجـهـ احترام و جايعاه فرد سـالمند نـزد فرزنــان، اطرافيـان، دوسـتان و جامعه بيشتر باشد و از تجربه و توانايىهايش استفاده شود، سالمند با اميدوارى و دلخرمى بيشترى به آغوش جامعـه بـاز مـى كـردد و حضور مجدد و مشاركت وى در عرصـهـــاى اجتمـاعى و مشـاغل مختلف، اميدبخش و نشاطآور خواهد بود(r). لازم به ذكر است كه در سـال • • + موسســى ملى سـالمندان، كنفرانسى علمى در زمينهى سوءرفتار با سالمندان بركزار كرد و اختصـاص اولويـت بــه تحقيقات در اين زمينه را توصيه نموده است. در سـال זا+؟ا، نيـز

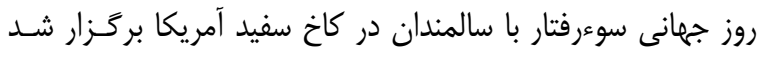
كه بر اهميت ايـن مسـئله تاكيــــدارد(أ). بـا وجـود اهميـت ايـن

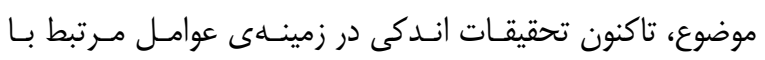
سوءرفتار با سـالمندان انجـام گرفتـه اسـت و در ميـان تحقيقـات صورت كرفته در شهرهاى مختلف ايران ميزان سوءرفتار با سالمند

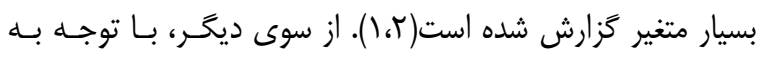
رويكرد اسلام در زمينـهى بهداشـت روان سـالمندان، كـه در ايـن زمينه به خانواده نقشى مهم واكذار مسى كنــــ و بـه بهـره كيـــى از 
9/.) و ثبات درونى از طريـق آزمـون مجـدد(99/•) مؤيـــــايـايى مطلوب اين يرسشنامه است. اين ابزار با برخوردارى از ويزگىهايى نظير طراحى براساس درك مفهوم سـوءرفتار از ديـدكاه سـالمندان ايرانى و مبتنى بر تجربيات زيستى آنان، تبيين طيف كامل اشـكال سوءرفتار با سالمند در خانواده، نمرهذارى سـاده، يايـيـى و روايسى مناسب و قابليت به كـارگيرى در موقعيـتهـاى مختلـف، ابـزارى مناسب جهت بررسى سوءرفتار با سـالمند در خـانوادهــاى ايرانسى است(9). در קِايان يّ از تكميل يرسشنامهها، دادهها با اسـتفاده از آمار توصيفى، آزمون كاىاسكور و ضريب همبسـتخى اسـبيرمن در نرم افزار SPSS نسخه عا مـورد تحليـل قـرار گرفتنـــ. (سـطح معنادارى آمارى ه+|•>P در نظر گرفته شد). بـهــلاوه، كليـهى ملاحظات اخلاقى از جمله اخذ مجوز از كميته اخلاق(كـــ اخـلاق: (IR.ABADANUMS.REC.1394.46)، كسب رضايت آَاهانه، محفوظ ماندن اطلاعات ثبت شده، تاكيد بر انتشار نتايج به صورت كلى و رعايت امانتدارى در استفاده از منابع در اين مطالعه

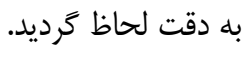

معيارهاى ورود به مطالعه شامل: سالمندان با سن •ع سال و بالاتر، سكونت در شهر آبادان، توانايى تكلم به زبـان فارسـى، توانـايى در پاسخخكويى به سوالات، عدم وجود مشـكل شـنوايى جـدى، عـدم وجود بيمارى تاييد شدهٔ روانسى و اخـتالاتلات شـناختى. معيارهـاى خروج از مطالعه شامل: زندَى كردن سـالمند در مراكـز نتحهـدارى سالمندان. يزوهششَّران پِ از كسب رضايت آكاهانـهـ از سـالمندان شركت كنتده در مطالعـه و توضـيح و تفهـيم اهــاف يـروهش بــه صورت شفاهى، فـرم اطلاعـات جمعيـتشـناختى و يرسشـناملى "اسوءرفتار نسبت به سالمند در خـانواده" را از طريـق مصـاحبه بـاـ سالمند تكميل مى كردند. مدت زمان مورد نياز جهـت تكميـل هـر يرسشنامه به طور متوسط • ب دقيقه بود. فرم اطلاعـات جمعيــشناختى حاوى سوالاتى در زمينهى: سن، جنس، قوميت، وضـعيت تاهل، تعداد فرزندان و در آمد ماهيانه بود. يرسشــامهى" سـوءرفتار نسبت به سالمند در خانواده 《 شامل جو عبارت در ^ زير مقيـاس: غفلـت مراقبتـى(لاعبـارت)، سـوءرفتار روانشــاختى(1 عبـارت)، سـوءرفتار جسـمى(أ عبـارت)، سـوءرفتار مـالى( ع عبـارت)، سـلب اختيار( • ( عبارت)، طردشدگى (أ عبارت)، غفلت مالى(أ عبـارت) و

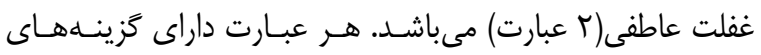

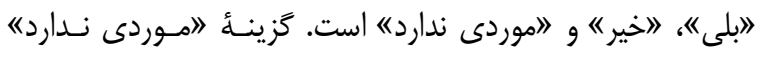
دلالت بر شرايطى دارد كه عبـارت مـورد نظــر بـا شـرايط زنـدكى سالمند، همخوانى و تناسب ندارد. امتيازهاى اخذ شده، در محـدوده • • • هستند و امتياز بالاتر نشاندهندهى وجود ميـزان بيشـترى از علائسم سـوءرفتار اسـتـ ايـن ابـزار توسـط هـروى كريمـوى و

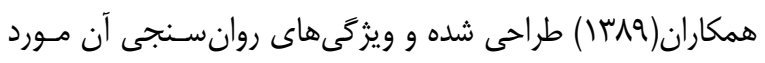
بررسى قرار گرفتهه است به طورى كه از اعتبـار صـورى، محتـوا و سازه برخوردار بوده و محاسبهى ضريب آلفـاى كرونبـاخ (9Vه/•ـ 


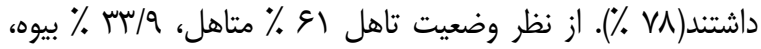

r/r/ \% مطلقه و r \% مجرد بودند و از نظر وضعيت درآمد ماهيانه در קايان، rOI يرسشنامه به طور كامل تكميل شدند. سن شركت-

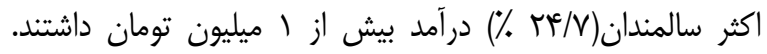

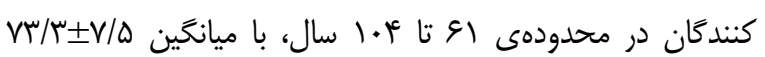

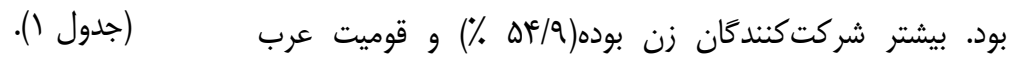

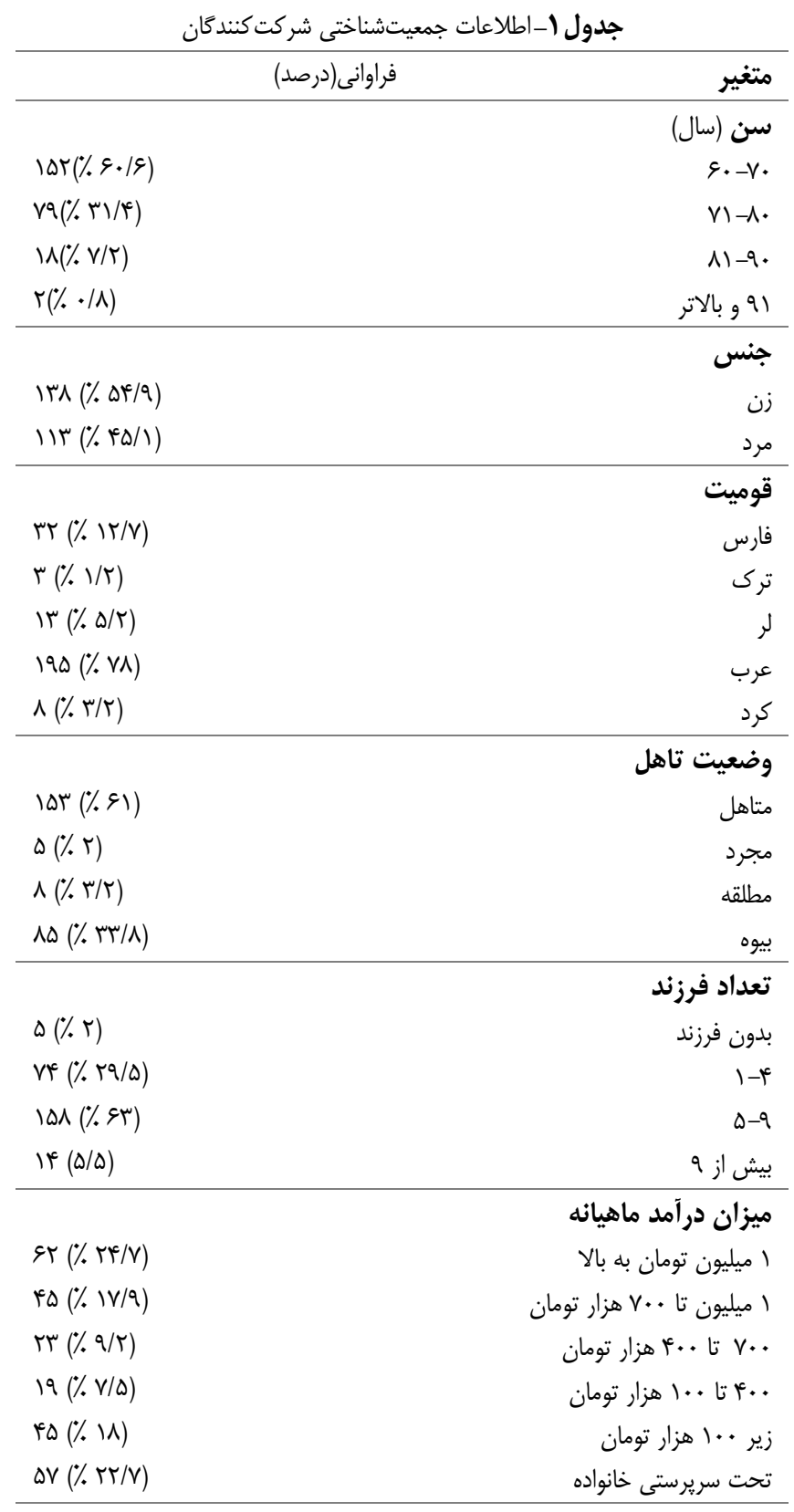




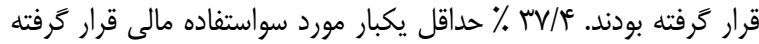

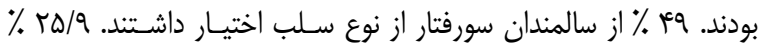

حداقل يكبار سابقه طردشدن و ₹r ٪ مورد غفلت مالى قرار كرفته بودند.

ץ/
به علاوه، مشخص شد كه از ميان سالمندان شـركت كنـــه، 9 \& ٪ از آنان در طول يكى سال كذشته حداقل يك مورد سـورفتار از نـوع غفلـت

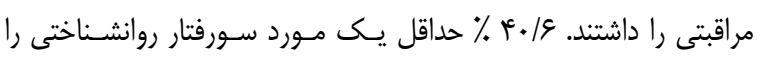
تجربه كرده بودند. ؟/Nץ ٪ از آنان حداقل يكبار مـورد سـورفتار جسمىى

جيطه: جدول ج- فراوانى حيطههاى سوءر فتار با سالمند در خانواده

\begin{tabular}{|c|c|c|}
\hline $9 r / 9$ & 101 & غفلت مراقبتى \\
\hline 4.18 & $1 . r$ & سوءرفتار روانشناختى \\
\hline$r N / T$ & n & سوءرفتار جسمى \\
\hline$r V / T^{c}$ & $9 f$ & سوءاستفاده مالى \\
\hline 19 & אזו & سلب اختيار \\
\hline$r \Delta / q$ & $9 \Delta$ & طرد شدن \\
\hline rV & $9 \pi$ & غفلت مالى \\
\hline ( & 91 & غفلت عاطفى \\
\hline
\end{tabular}

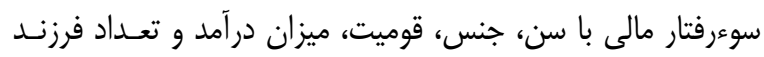
ارتباط معنـادارى نداشـت امـا، بـين سـوءرفتار مـالى بـا وضـعيت

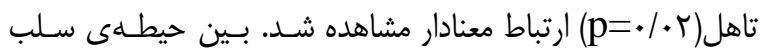
اختيار با سن، جنس، قوميت و ميزان درآمد ارتبــاط معنـادار وجـود نداشت در حالى كه، بين سلب اختيار با تاهـل( ( +./. ارتبـاط معـــادار ديــده شــد، همجرنـين بــين سـلب اختيـار بــا تعـداد فرزندان(1 +./p= ارتباط معنـادار معكـوس وجـود داشـت. بـين حيطهى طردشدكى با سن، جنس، وضعيت تاهل، قوميت و ميـزان درآمد ارتباط معنادار وجود نداشت، ولى بين طرد شـدگى بـا تعـداد

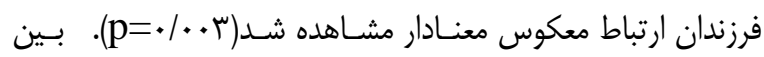
حيطهى غفلت مالى با سن، جنس، قوميت ارتباط معنادار ديده نشد.

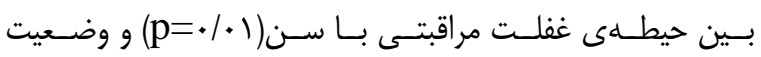

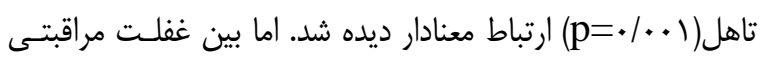
با جنس، قوميت، تعداد فرزند و درآمد ماهيانـهـ اخـتلاف معنــادارى وجود نداشت. بين حيطهى سوءرفتار روانشناختى بــا سـن، جـنس، قوميت و درآمد ماهيانه ارتباط آمارى معنادار وجود نداشت اما، بـين سوءرفتار روانشناختى با وضعيت تاهل( (p= p) و تعـداد فرزنـــ

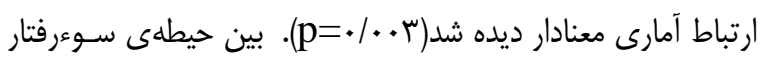
جسمى با جنس، وضـعيت تاهـل، قوميـت و تعـداد فرزنـــ ارتبـاط معنادار وجود نداشت اما، ارتباط معنادار بين سوءرفتار جسمى و سن

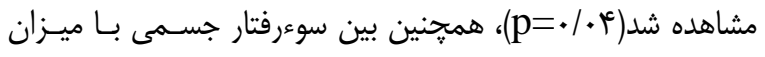

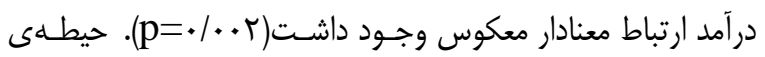


غفلت عاطفى با سن، جنس و قوميت ارتباط معنادارى نداشت، امـا

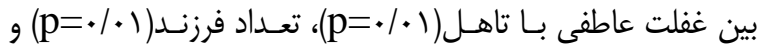
درآمد ماهيانه(ץ-/p=| ارتباط معنادار ديده شد(جدول ץ).

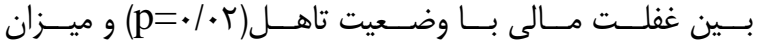

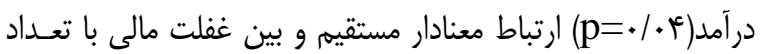

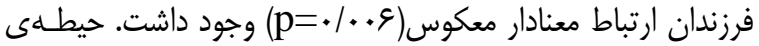

جدول ب- ارتباط بين حيطههاى سوءرفتار در سالمندان با برخى متغيرهاى جمعيتشناختى

\begin{tabular}{|c|c|c|c|c|c|c|}
\hline درآمد ماهيانه* & تعداد فرزند** & قوميت* & تاهل:"* & جنس*** & سن & حتيطه: \\
\hline (ז//. & .1 .9 & $. / 9)^{\circ}$ & $.1 . .1$ &.$/ T V$ & .1 .1 & غفلت مراقبتى \\
\hline.$/ 1 S$ &.$/ . \mu$ &.$/ \Gamma$ & $.1 \cdot .1$ &.$/ A V$ & . $/ \Delta T$ & سوءرفتار روانشناختى \\
\hline$(-) \cdot / \cdot \cdot r$ & .1 .9 &.$/ 9$ & $\cdot|r|$ & .191 & .1 .4 & سوءرفتار جسمى \\
\hline .119 & .111 &.$/ 1 r$ & $.1 . r$ &.$/ 49$ & $\cdot / \Delta \Delta$ & سوءاستفاده مالى \\
\hline .119 & $(-) \cdot 1 \cdot \cdot 1$ &.$/ \mathrm{VV}$ & $.1 . .1$ &.$|9|$ &.$/ 4 T$ & سلب اختيار \\
\hline.$/ 01$ & $(-) \cdot / \cdot \cdot r$ & .199 & $\cdot / \mathrm{N}^{4}$ &.$/ \mu$ & $\cdot / 1$ & طرد شدن \\
\hline .1 .4 & $(-) \cdot / \cdot .9$ &.$/ \mu$ & .1 .4 & .1 .9 & . & غفلت مالى \\
\hline $.1 \cdot 4$ & $.1 \cdot 1$ &.$|9|$ & .1 .1 &.$/ \mu F$ &.$/ 41$ & غفلت عاطفى \\
\hline & & & & & & 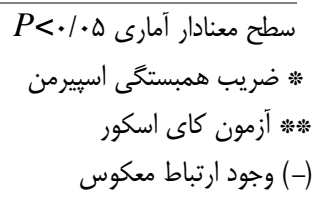 \\
\hline
\end{tabular}

مراقبتى(9/9 \%) است. در اين زمينه نورى و همكاران نشان داده-

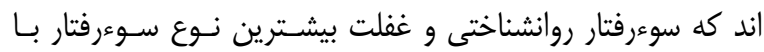
سالمند بوده است و ميزان سوءرفتار از نـوع سـلب اختيـار س/r ٪ \% بوده است(T) كه اين ميزان بسيار كمتر از مقادير حاصل از مطالعهى حاضر مىباشد. در راستاى يزوهش حاضـر، هـروى كريمـوى در مطالعهى كيفى خود يكى از جنبههاى بسيار مهم يديـدار شـده در تجربيـات سـالمندان را سـلب اختيـار عنـوان كـرده اسـت و اكثـر سالمندان نداشتن حـق انتخـاب، فقـدان فضـاى شخصىى، وجـود محدوديت در برقرارى ارتباط با ديخران و تصميمَيـرى بــه جـاى سالمند را گزارش كردهاند(9). در يزوهش منوجهرى و همكاران نيز

\section{بحث و نتيجلَيرى}

يديدهى سالمندى آزارى اخيرا به عنوان يك خالش مهمم در حيطهى مراقبت از سالمند و يكى معضـل اجتمـاعى گسـترده و در حـال رشد در سراسر جهان مطرح كرديده است كه تهديدكنتـدهى بقـاو كيفيت زندگى سالمندان مىباشد، لذا اين يزوهش به منظور تعيـين برخى عوامل مرتبط با سوءرفتار با سالمند در خـانواده انجـام شــه

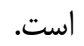
جنانجه ملاحظه مىشود، نتايج حاكى آن است كـه بيشـترين نـوع

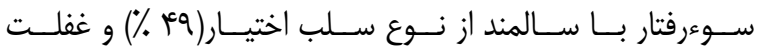


مورد سوءرفتار جسمى قرار گرَفتهاند، در حالى كه در يزوهش نورى

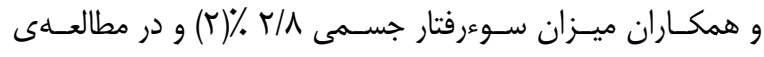
Skirbekk

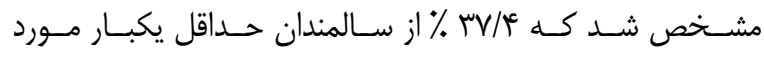
سوءاستفاده مالى و بيش از \r ٪ از سالمندان مـورد غفلـت مـالى قـرار كَرفتـهانــد، در زمينـهـى سوءاسـتفادهى مـالى در سـالمندان،

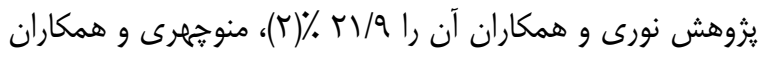

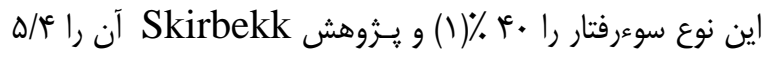
\% كزارش كردهاند(ه)، يكى از دلائل وجود ايـن نـوع سـوءرفتار را مىتوان ناشى از صنعتى شدن جوامع و معضـاتلات اقتصـادى طـى سالهاى اخير دانست كه منجر به كاهش قدرت حمايتهاى مالى فرزندان و در نتيجه بروز اين معضل شده است. همجنين مشخص شد كه س/عץ \% از سالمندان حداقل يكبار مورد غفلت عاطفى قـرار

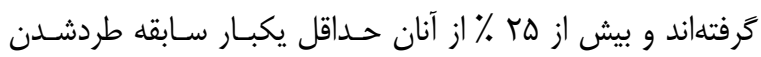
داشتهاند، در يزوهش نورى و همكاران غفلت عاطفى در سالمندان

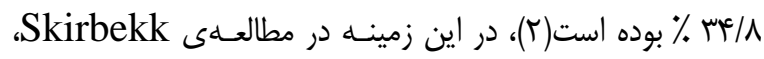
سوءرفتار از نوع بىاحترامى 9 \% كزارش شــه اسـت(ه). هـروىكريموى نيز در مطالعهى خود بيان كرده است كه اكثر سـالمندان

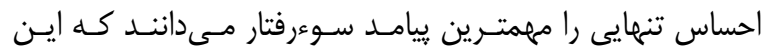
احساس تنهايى نتيجهى بىتوجهى، رهاشدگى، بهـرهشى مـالى، تحميل آزارهاى روانشناختى و فقدان حمايت عاطفى مىباشـد(9). در اين زمينه شايد بتوان بروز سوءرفتار و غفلت عاطفى را بـه نــوع رابطهى فرزند- والـــ و همجنــين انتظـارات والـدين از فرزنــان و فرزندان از والدين مرتبط دانسـت، از سـوى ديخـــر زنـــى مـدرن امروزى و كمبود وقت و تمركز فرزندان براى رسيدگى به نيازهـاى
مشخص شده است كه بيش از NV ٪ از سـالمندان حـداقل يكبـار مورد سوءرفتار قرار گرفتهاند كه در اين ميـان سـوءرفتار عـاطفى و غفلت بيشترين نوع سوءرفتار بوده است و ميزان غفلت \&V ٪ و تـا

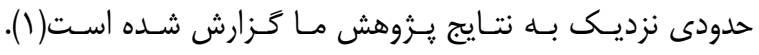
Acierno بيشترين نوع سوءرفتار شناسايى كردهاند(أl). اين در حـالى اسـت كه مطالعهى Skirbekk و همكاران در كشـور هنــ نشـان داده است كه حدود || ٪ از سالمندان حـداقل يـك نـوع سـوءرفتار را تجربه كردهاند كه بيشتر از نوع كلامى و بـاحترامى بـوده و فقـط ه/r \% از موارد سوءرفتار از نوع غفلت بـوده اسـت(ه). بــهـ عـلاوه، آمارهاى مربوط به ميـزان سـوءرفتار در آمريكـا ــ ٪ (5)، روسـيه

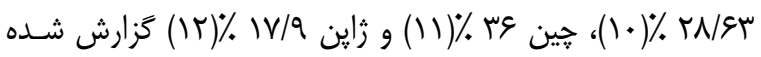
است. جنانجه ملاحظه مىشود آمار ارائه شده در ايران بسيار بالاتر از ساير كشورها است، وجود اختلاف در ميزان فراوانى گزارش شده در مطالعات فوق را شايد بتوان ناشى از وجود تفاوتهاى فرهنگىى بين جوامع، عدم وجود تعريف مشخص از مفهوم سوءرفتار، استفاده از ابزارهاى مختلف جهت سنجش سوءرفتار و وجـود تفـاوتهـاى متدولوزيك در مطالعات دانست، كه مانعى جهت مقايسهى علمى يافته ها مىباشد. يافتهها نشان مىدهد حدود \&/٪ ٪ از سالمندان حداقل يك مورد سوءرفتار روانشناختى را تجربه كردهاند كـه در مطالعـى نـورى و

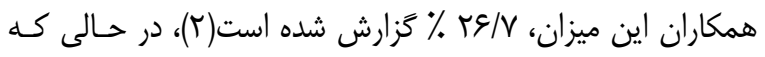

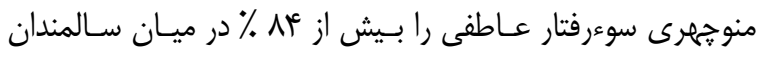
كزارش كرده است(1)، Amstadter و همكـاران نيـز بيشـترين ميزان سوءرفتار را از نوع روانشناختى گزارش كردهانـد(سا). نتـايج همجنين بيانكر آن است كـه س/N ٪ از سـالمندان حـداقل يكبـار 
سالمند رابطهُ معنىدار مشاهده شده است، بدين معنا كه با افزايش سن سالمند، ميزان سوءرفتار افزايش يافته و از طرفى بين سوءرفتار و جنس، وضـعيت تأهـل، نحـوهى زنــدَى و ناحيـهى جغرافيـايى رابطهى معنىدارى يافت نشده است(1) كه از اين نظر تا حـدودى مغاير با نتايج يزوهش حاضر مىباشد. على رغه تاكيد فراوان فرهنَ و دين كشور ما در زمينهى ارتبـاط با سالمند، نتايج اين يُوهش نشان داد كه سوءرفتار با سـالمند بــه عنوان يك خالش مهرم در ميان سالمندان وجود دارد به طورى كـهـ تعداد زيادى از سالمندان در معرض انواع سـوءرفتار قـرار داشـته و سوءرفتار از نوع غفلت مراقبتى و سـلب اختيـار در آنـان بيشـترين ميزان را دارد. همرِنين مشخص شد فاكتورهـايى همجـون سـن، تاهل، تعداد فرزند و درآمد از جمله عوامل مــرتبط بــا حيطـهـهـاى مختلف سوءرفتار با سالمند مىباشد. لذا، بـا توجـهـ بــهـ بـالا بـودن ميزان سوءرفتار با سالمند در خانواده، همكارى و مشاركت كليـهى سازمانهاى دستاندركار امرى ضرورى به نظر مىسد و اميد است نتايج يزوهش حاضر بتوانــد نـــــ عميـقتـر و دقيـقتـرى را در مسئولين بهداشتى كشور ايجـاد كنـد تـا كَامى مـوثر در راسـتاى شناسايى قربانيان سوءرفتار و ارائهى خدمات موثر در مرتفع كـردن اين معضل مهم بهراشتى برداشته شود. بهعلاوه، لازم به ذكر است كه در اين يثرهش فقط سالمندان بسترى در بيمارسـتانهـا مـورد مطالعه قرار گرفتند و ساير سالمندان جامعه وارد مطالعه نشدند كـهـ اين امر شايد بتواند در نتايج تاثير گذار باشد، لذا بايد اين مسئله را از محدوديتهاى اين يثروش برشمرد و در تعميم يافتـههــا بـهـ كـل جامعهى سالمندان جوانب احتياط را در نظر داشت.
والدين را يكى ديخر از دلايل احتمالى بروز اين نوع سوءرفتار مى-

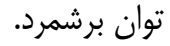

بخش ديخرى از يافتهها نشان مىدهد كه بين غفلـت مراقبتى بـا سن سالمند و وضعيت تاهل، بين سوءرفتار روانشناختى با وضـعيت تاهل و تعداد فرزندان سالمند، بين سوءرفتار جسمى با سن و درآمد

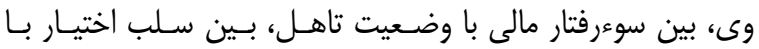
وضعيت تاهل و تعداد فرزندان، بين طردشدگى با تعـداد فرزنـدان، بين غفلت مالى با وضعيت تاهل، تعداد فرزندان سالمند و درآمــد و بين غفلت عاطفى با تاهل، تعداد فرزندان و درآمــد ارتبـاط معنـادار وجود دارد. در ايسن زمينـهـ مسىـــوان بــهـ نتـايج يـروهش نـورى و همكاران اشاره كرد كه به طور كلى بين سوءرفتار در سالمندان بـاــا سطح درآمد خانواده و وضعيت تاهل سالمند ارتبـاط معنـادار وجـود داشته است(r) كه بـا نتـايج يـرثوهش حاضـر همراسـتا مـىباشـد. نيز در يـروهش خـود نشـان داده اسـت كـهـ سـطح تحصيل سالمندان با بروز سوءرفتار توسط آنان ارتباط دارد، و تعداد اعضاى زياد خانواده احتمال سوءرفتار را كاهش مىدهــد، در حـالى كه داشتن تعداد بيشترى از كودكـان در خـانوادهى فرزنـــ شـانس ســوءرفتار (غفلـت و آزار كلامــى) را افــزايش مـــدهــد(ه). در يزوهش Gabriella Melchiorre نيز مشخص شـده اسـت كه داشتن سطوح پايين حمايت اجتماعى با سوءرفتار و مخصوصا" سوءرفتار روانشناختى در سالمندان مـرتبط بـوده و داشـتن سـطوح بالاى حمايت اجتماعى بــه عنـوان فاكتورهـاى حمايست كنتــده در كاهش آسيبيذيرى افراد سالمند و سوءرفتار با سـالمندان شـناخته شده است((). در يزوهش منوخهرى هم بين بروز سوءرفتار با سـن 


$$
\begin{aligned}
& \text { فصلنامه هبستارى سائمندان } \\
& \text { تقدير و تشكر } \\
& \text { در پايان، نظر به اين كه يزوهش حاضر، نتيجهى طـرح تحقيقـاتى يزوهشى اين دانشـكده و از تمـامى عزيزانى كـه در اجـراى ايـن }
\end{aligned}
$$

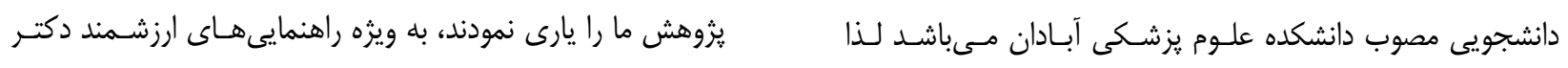

$$
\begin{aligned}
& \text { هروى كريموى تشكر و قدردانى نمايند. }
\end{aligned}
$$

\section{- References}

1. Maneuchehry H, Ghorby B. The amount and types of domestic abuse in the elderly referred to Park lyrics Tehran. Journal of School of Nursing and Midwifery Beheshti 2008; 18(62): 37-43.

2. Nori A, Ragaby A, Esmaiil Zade F. Elderly abuse in kalale Township. Journal of Gorgan University of Medical Sciences 2013; 16(4): 93-98.

3. Heravy Karimvy M, Anoshe M, Sheikhy M. Perception of elderly women about the phenomenon of elder abuse. Journal of School of Nursing and Midwifery Shahid Beheshti 2008; 18(61): 28 .

4. Xinqi Dong. Elder Abuse: Research, Practice, and Health Policy the 2012 GSA Maxwell Pollack Award Lecture. The Gerontologist 2014; 54(2): 153-162.

5. Skirbekk V, James K. Abuse against elderly in India - The role of education. BMC Public Health 2014; 14(336): 1471-58.

6. Gabriella Melchiorre M. Social Support, Socio-Economic Status, Health and Abuse among Older People in Seven European Countries. PLoS ONE 2013; 8(1): e54856. doi:10.1371/journal.pone.0054856.

7. Enguidanos S, DeLiema M. Multicultural voices: Attitudes of older adults in the United States about elder mistreatment. NIH Public Access 2014; 34(5): 877-903.

8. Heravy Karimvy M, Anoshe M. An exploration into the lived experiences of elders regarding abuse by family members. Nursing Research 2010; 5(18): 6-17. 
9. Heravy Karimvy M, Anoshe M, Forughan M, Sheykhi MT, Hajizadeh E. Design and psychometric of elder abuse questionnaire in family. Iranian Aging Journal 2010; 5(15): 7-21.

10. Puchkov P. Elder abuse: current research in the Russian Federation 2004-2006. Journal of adult protection 2006; 8(4): 4-12.

11. Wu L, Chen H, Hu Y, Xiang H, Yu X, Zhang T, et al. Prevalence and associated factors of elder mistreatment in a rural community in People's Republic of China: A cross-sectional study. PloS One 2012; 7(3): e33857.

12. Anme T, McCall M, Tatara T. An exploratory study of abuse among frail elders using services in a small village in Japan. Journal of elder abuse and neglect 2006; 17(2): 1-20.

13. Amstadter AB, Zajac K, Strachan M, Hernandez MA, Kilpatrick DG, Acierno R. Prevalence and correlates of elder mistreatment in South Carolina: The South Carolina elder mistreatment study. J Interpers Violence 2011; 26(15): 2947-72.

14. Acierno R, Hernandez MA, Amstadter AB, Resnick HS, Steve K, Muzzy W, et al. Prevalence and correlates of emotional, physical, sexual, and financial abuse and potential neglect in the United States: The national elder mistreatment study. American Journal of Public Health 2010; 100(2): 292-7. 